\title{
РАЗГОВОРНИ ЈЕЗИК У УСВАЈАҢУ СРПСКОГ КАО СТРАНОГ ЈЕЗИКА
}

\begin{abstract}
Развијање комуникативне компетенције у учењу страног језика постојало је и у прошлости, мада се почев од осамдесетих година 20. века у савременој методици указује на њено централно место у настави страног језика па и српског, од најранијих фаза учења. У реферату ће се поћи од теоријског оквира и дефиниције комуникативне компетенције и посебно природних облика комуникације (дијалог). Затим ће се анализирати примери дијалога као најчешћег облика вербалне интеракције у неколико уџбеника српског као страног. Циљ је да се одговори на питање да ли дијалози у дидактичком материјалу на располагању наставницима у раду са страним студентима одговарају реалној/природној ситуацији и које/какве културолошке поруке нуде.
\end{abstract}

Кључне речи: српски као страни језик, комуникација, разговорни језик, дијалог.

\section{1. Увод}

Предмет овог реферата је разговор као најприроднији облик комуникације и дијалог као једна од његових форми и најважнијих језичких способности при усвајању сваког страног језика, па и српског. У уводном делу бавимо се теоријским оквиром, дефиницијом разговорног језика и дијалога, те анализом примера у неколико уџбеника српског за странце које користимо у настави са италофонима. Наше полазиште је да је дијалог у уџбеницима српског као страног језика важан пре свега због аутентичних елемената изворног/говорног језика и елемената културе које садржи или би требало да садржи, а са којима студенти долазе у контакт у артифицијелном и иностраном контексту. Анализа примера ће показати да ли и у којој мери уџбеници задовољавају критеријуме савремене наставе са циљем не да се они вреднују, него да се укаже на мањкавости и предности које би биле корисне ауторима и будућим издањима.

*1jiljana.banjanin@unito.it 


\section{2. Разговорни језик и његове форме}

Почев од осамдесетих година XX века, у глотодидактици и методици наставе као и у лингвистичким размишљањима о учењу страног језика, наметнуло се схватање о превласти усмене комуникације у односу на писмену, на свим нивоима (Бибер 1988). У прилог томе лингвисти истичу на првом месту да историјски гледано, усмено изражавање претходи писменом, да се индивидуално усвајање језика појединца реализује такође од усменог ка писаном, да се у пракси комуникација тј. социјална и културна интеракција манифестују пре свега путем говора, и најзад, да говорни језик располаже паралингвистичким средствима која само делимично могу да се пренесу у писану форму. Прво питање у вези са овим је шта се подразумева под говорним језиком, у ком смислу се користи овај вишезначни термин који се преклапа са неким другим терминима као што су оралност, гласовни и аудитивни систем, лингвистички варијетети, као и које место заузима дијалог у оквиру категорије говорног језика.

Полазећи од теоријских поставки (в. Бацанела 1994, Бацанела 2002) говорни језик се посматра као активност и језичка варијанта која се реализује преко гласовног канала у одређеном социјалном контексту, тј. у ситуацији чији су саставни део лингвистички, али и нелингвистички аспекти као и одређена металингвистичка компетенција која зависи од ситуације у којој се говор реализује. Он се разликује од писменог изражавања пре свега по непосредности која условљава садржај изговореног. Због тога говор често није организован, недовољно је артикулисан, обилује паузама, понављањима, исправкама, лексички и граматички је непрецизан, тематски нелинеаран, за разлику од писаног текста који је артикулисан и кохерентан како на семантичком тако и на лингвистичком плану.

Кључне речи у свим дефиницијама дијалога ${ }^{1}$ су интеракција, вербални (или знаковни) систем, размена информација и идеја као и орална комуникација, а то су они елементи који су битни у усвајању страног језика, па и српског, од самог почетка његовог учења. За разлику од методичких постулата који су у прошлости привилеговали граматичку компетенцију, ригорозно и често изоловано познавање граматичких правила, језичких промена и синтагматске структуре ван природног контекста, ${ }^{2}$ данас се велика пажња

\footnotetext{
${ }^{1}$ Доносимо илустративно само неколико примера дефиниција дијалога у речницима и лексиконима. Клајн и Шипка, на пример, дефинишу дијалог као разговор, оралну комуникацију између два саговорника у разним контекстима или као разговор уопште, преговор, размену мишљења и различитих ставова (2010: 368). По Де Мауру (2004) дијалог је конверзација између два или више говорника који размењују мишљења и идеје како би дошли до заједничког става. Цингарели (1970), између осталог, наводи дијалог као музички термин али и политичку категорију и прецизира да је то увек конверзација између два или више лица, чији се искази надовезују и следе један за другим алтернативно.

${ }^{2}$ Један од најлепших примера граматичке методе у учењу страног језика дао је Бранислав Нушић у својој Аутобиографији, илуструјући Олендорфову методу у учењу француског језика и стога наводимо овде један одломак:
}

„Питање: Брат ваше жене, има ли он једну тицу која лепо пева?

Одговор: Да, брат моје жене има једну тицу која лепо пева! 
посвећује и комуникацијској компетенцији. Она подразумева језичку/граматичку компетенцију, тј. познавање лингвистичких структура, социолингвистичку компетенцију или познавање правила о прихватљивости језичких израза у једној језичкој заједници и прагматичку или стратегијску компетенцију (в. Хаџи Пожгај 1999: 652, Вилић 2007: 224) која је дефинисана Заједничким европским референтним оквиром (ЗЕРОЈ 2005).

Познавање граматичких структура једног страног језика, правила којима се комбинују његови елементи, познавање лексике и способност правилног коришћења свих ових елемената потребни су али не и довољни за коректну употребу у комуникацији, у датој средини и окружењу изворних говорника. Када се ради о циљевима који се постављају на универзитетском нивоу, од студената се очекује и захтева да уз оперативну граматику овладају и слушањем и употребом језика у реалним и конкретним ситуацијама, а то се остварује кроз конверзацију, дијалог и комуникацију. Студенти треба да буду у стању не само да апсорбују него и да размењују поруке и формуле као равноправни учесници у разговору. Док се традиционална лингвистика заснивала на анализи израза изолованих из контекста, онога што теоретичари називају speech acts (Пјаца 1995), данас је фокус проширен и на анализу спонтаног и неформалног говора чији је саставни елеменат и дијалог као део свакодневне комуникације, пошто језик у друштвеном контексту није и не треба да буде механички скуп реченица већ спонтано и природно изражавање у свакодневним ситуацијама (породица, факултет, јавна места: биоскоп, позориште, концерт, улица, ресторан, пијаца, апотека, пошта, железничка станица итд.).

Спонтани разговор, конверзација и дијалог као његова најтипичнија форма, има одређену структуру и саставне делове: основна јединица је 'исказ', тј. реченица или неки њен део који врши акцију (поздрављање, постављање питања, на пример) и дефинише се као 'турнус'/turn-taking (Пјаца 1995: 87), који неки теоретичари називају једноставно 'разменом' (Маркарино 1997, Стевић 2007). Према томе, језичка размена је синоним за смењивање турнуса (Стевић 2007: 93), при чему треба нагласити да у оралној комуникацији важну улогу имају и неки други елементи који су често запостављени, као на пример пауза. Њена функција је одлагање и говорник је користи како би избегао директан одговор, служи му да размисли и организује мисли. Паузу обично прате речце, узвици, уздаси и сл.: ех/ax/ox/yx, хммм..., па, онда, овај, знаш, видиш... и др.

Део дијалога су и следови који се дефинишу као минимални дводелни склоп са типичном акцијом питање - одговор, која се састоји од најмање две акције различитих говорника. Као најтипичнији пример за след могу да послуже позив - одзив, поздрав - отпоздрав, питање - процена - одговор. Нарочито су важни следови чија је улога отварање и затварање дијалога, а

Питање: Није ли ваша сестра од тетке род сестри од тетке мојега нећака?

Одговор: Да, моја је сестра од тетке род сестри од тетке вашега нећака!

Питање: Јесте ли видели ножић мога стрица?

Одговор: Да, видео сам ножић вашега стрица на клупи у башти моје тетке, која је јуче појела једну јабуку” (Нушић 1962: 123). 
то су поздрави и питања (Добар дан! Здраво, ћао! Како си? Шта радиш? Где си? Шта има ново?), после чега следи предмет конверзације или дијалога. Крају, тј. затварању претходи прелиминарна акција (предзатварање), а следи закључна размена која представља крај дијалога и терминални поздрави (У реду! Важи! Добро! Видимо се! Ћао! Здраво!).

\section{3. Дијалози у уџбеницима српског као страног језика}

Дијалози у уџбеницима страног језика требало би да симулирају реалне животне ситуације и да буду нека врста преснимљене реалности и да својом спонтаношћу одговарају реалним ситуацијама јер представљају варијанте „звучног записа одређене спонтане комуникацијске ситуације” (Пожгај Хаџи/Смолић 1996: 192-197). У пракси се они у уџбеницима српског као страног језика користе веома често и на свим нивоима, најчешће као дидактички материјал са циљем да илуструју граматички исправну формулу која се користи у свакодневном говору. То је полазиште овог рада у коме ћемо из објективних разлога на врло органиченом броју примера моћи да анализирамо дијалоге, укажемо на њихову структуру и функцију, било да се ради о најједноставнијим дијалозима који се користе на почетном нивоу или о комплекснијим. Одабрали смо приручнике које смо користили и користимо у настави са страним студентима (Ћорић 2002; Алановић и др. 2007; Бјелаковић и др. 2004; Милићевић Добромиров и др. 2006; Милићевић Добромиров/Новковић 2009), примењујући модификовану и потребама овог рада прилагођену етнометодолошку методу која омогућава да се дијалог профилише и да се уоче неки његови типични делови и карактеристике (Стати 1982; Стевић 2007). Свакодневне акције (говор) и одговори на њих могу бити пожељни, преференцијски и непреференцијски; неке акције нам се „намећу” и препоручују, друге не, и чак се искључују. Основна особина преференцијског одговора је да се реализује на једноставан начин, тако што се позив прихвата, док је непреференцијско одбијање сложеније и укључује неку врсту објашњења, оправдања и/или извињења, као што ће илустровати примери.

(1) - Шта је оно?

- Оно је лопта.

- Ово је шешир. Ово није лопта.

- Да. То је шешир, то није лопта.

- Ко је оно?

- Оно је мушкарац.

- Ово је жена. Ово није мушкарац.

- Да, то је жена. Оно је мушкарац.

- Ово је Ваш шешир?

- Не, то није мој шешир.

- То је његов шешир.

- Да, то је мој шешир. 
- Ко сте Ви?

- Ја сам Новак Вуковић.

- Ко сте ви?

- Ми? Ми смо Игор и Дарко.

- Ти си Игор?

- Не, ја нисам Игор. Ја сам Дарко. Моје име је Дарко. Он је Игор.

Његово име је Игор.

- Твоје име је Игор?

- Да. Ја сам Игор. Моје име је Игор.

- А ваше презиме?

- Наше презиме је Костић.

- Ви сте Игор и Дарко Костић.

- Да ли је ово твоја улица?

- Да, ово је наша улица.

- Је ли ово твоја кућа?

- Не, то није моја кућа. Оно је моја кућа (Ћорић 2002: 13-15). ${ }^{3}$

(2) - Новаче, шта радите?

- Тражим упаљач.

- Ви не знате где је Ваш упаљач?

- Не знам где је.

- Имате га у руци!

- О, да (Ћорић 2002: 99).

Оба дијалога преузета су из Ћорићевог приручника Српски за странце из 2002. г. Ради се о седмом издању уџбеника чији је наслов до 1995. г. гласио Српско-хрватски за страние, а после тога су издања ажурирана са измењеним насловом и са делимично измењеним садржајем. Оба дијалога су из прве лекције насловљене „Мој шешир”. Почетак дијалога (1) између саговорника карактеришу турнуси које уводи Новак Вуковић, лик који се прати као главни протагониста од прве до последње лекције. У овој првој лекцији у којој се користи дијалог као најнепосреднији облик комуникације, он поставља питања директно и без увода или поздрава што би било у складу са свакодневним опхођењем („Добар дан”; „Здраво”, на пример). Прво питање које аутор уводи у првој лекцији и у овом облику сматрамо да није уобичајено за реалну говорну ситуацију, нарочито ако се има у виду да се ради о комуникацији између генерацијски различитих говорника/саговорника: одраслог Новака Вуковића и младих/деце као у овом случају, те да се ради о особама које међусобно нису присне, ни у пријатељским односима. Близински пар Новак Вуковић са једне, и Дарко и Игор Костић са друге стране, нису уклопљени у одговарајући реалан и реалистички контекст, па дијалог делује артифицијелно и нестимулативно као приступ теми представљања и увођења главних актера наставних јединица који ће се јављати кроз приручник. Аутор очигледно није сматрао да дијалог треба да буде аутентичан јер је фокус пре свега на

\footnotetext{
${ }^{3}$ Овај као и сви остали дијалози у приручницима су представљени латиничним писмом.
} 
увођењу и варирању основних и за почетни ниво неопходних граматичких форми: именица мушког и женског рода (шешир, лопта, мушкарац, жена, кућа, улица, име, презиме), глагола 'бити' у презенту једнине и множине, афирмативног, одричног, упитног облика и инверзије.

У дијалогу (2) поступак је сличан, с том разликом што се дијалог отвара на начин који је типичан за говорну размену (, [...], шта радите?”). Близински пар је уобичајен и студенти одмах запажају да се ради о саговорницима који се познају, мада не постоје блиске релације, на шта указује форма обраћања (Ви), облик 2. л. множине глагола (радити, знати, имати) као и облик присвојне заменице за 2. л. мн. (Ваш). Комуникацијски одговор је преференцијалан, саговорник прихвата и одговара на питање, турнуси су економични и информацијски једноставни, што одговара реалној комуникацији, а то потврђује и последња реплика („О, да!”) која делује аутентично и спонтано, као реакција. Ипак, од реалне ситуације одудара и удаљава се трагање за упаљачем који је у руци Новака Вуковића, што је мало вероватно у реалној ситуацији и под нормалним околностима. Значи, и овде је дијалог артифицијелно структуриран, циљ није упознавање са аутентичним обрасцем и реализовање дијалошке функције, него савладавање граматичких знања (акузатив, локатив, вокатив именица, деклинација личних и присвојних заменица и др.).

Следећи примери лоцирани су у свакодневним ситуацијама (апотека, пекара, ресторан) и преузети су из три уџбеника: ауторки Милићевић Добромиров и Новковић (2009), групе аутора из Н. Сада (Алановић и др. 2006) и Ћорића (2002).

(3) А: Добар дан. Треба ми аспирин.

Б: Изволите, желите ли још нешто?

А: Знате, имам температуру. Кажите ми, шта је добро?

Б: Када имате температуру, треба Вам витамин Ц и аспирин. Треба да спавате, да се одмарате. Не треба да радите.

А: Добро, дајте ми аспирин, витамин Ц и можда неки чај.

Б: Да, да, чај је важан. Кажите ми, какав чај желите?

A: Какве чајеве имате?

Б: О, имамо све чајеве: воћне, биљне, црни, зелени, бели...

А: Добро, дајте ми биљни чај.

Б: Може ли камилица?

А: Да, може.

Б: Да ли је то све? Желите ли још нешто?

А: Не, то је све. (Милићевић Добромиров/Новковић 2009: 48).

(4) Муштерија: Добар дан. Колико кошта хлеб?

Продавац: Двадесет динара.

Муштерија: А кифла?

Продавац: Десет динара.

Муштерија: Добро. Желим хлеб и кифлу.

Продавац: То је тридесет динара. Желите ли још нешто?

Муштерија: Да, јогурт и млеко. 
Продавац: Изволите, осамдесет динара.

Муштерија: У реду. Изволите. До виђења.

Продавац: Пријатно (Алановић и др., 2006: 37).

(5) - Добро вече, Шта желите?

- Шта имате за јело?

- Имамо све што желите.

- Ми желимо јела са роштиља.

- На жалост, немамо јела са роштиља. Касно је. Роштиљ не ради.

- Колико је сати?

- Сада је пола једанаест.

- Али није касно, ви радите до дванаест.

- Не радимо до дванаест. Радимо до једанаест.

- А зашто говорите: „Имамо све што желите”?

- То говорим од три сата после подне.

- У реду. Шта имате за пиће?

- Имамо све што хоћете.

- Ја хоћу пиво. А ти, Зоро? Хоћеш ли и ти пиво?

- Нећу. Хоћу воћни сок.

- Имамо добре воћне сокове (Ћорић 2002: 151-152).

У дијалозима (3) и (4) препознаје се форма упарених исказа за коју је карактеристичан дводелни склоп. То значи да први део изискује други и дијалог се одвија по систему прихватања или одбијања, на уобичајен, реалистичан и сасвим умесан/могућ начин комуникације карактеристичне за апотеку и пекару (А - Б; муштерија - продавац). Свакодневном језичком изразу одговарају формуле у оба примера: „Добар дан”; „Желите ли још нешто?”, „Да ли је то све?”, „Изволите”; „У реду”; „То је све”; „Пријатно”. Акценат је на граматичким јединицама, на употреби глагола 'требати' (треба ми, не/треба да...), на употреби датива личне заменице у енклитичком облику („Треба ми”; „Кажите ми”; „Дајте ми”), на употреби бројева. Све је то успешно уклопљено у текст и сасвим - или у доброј мери - одговара природном језичком изразу. Насупрот томе, дијалог (5) у ресторану/кафани који се води између Новака и конобара није адекватан мада уводне реплике и турнуси наговештавају реалну говорну размену. Информације које даје конобар али и питања која поставља Новак одударају од формалних захтева комуникације у датој ситуацији. Искази „Имамо све што желите”, „А зашто говорите: „Имамо све што желите!” и „То говорим од три сата после подне” неприродни су и неаутентични облик дијалога између особља ресторана и госта: Новак се понаша непримерено ситуацији, а конобар уз то одаје и утисак незаинтересованости за свој посао и за госте пред собом. Страни студенти то одмах запажају и везују за неке стереотипне слике о странцима као што су непредузимљивост, индиферентност, незаинтересованост за учинак на радном месту, што опет води до погрешне перцепције читавог српског друштва. Овај пример илуструје опасност која у уџбеницима прети од фолклоризације тј. свега онога што се перципира као стереотипно, анегдотско и чудно у страној цивилиза- 
цији, у овом случају српској, а на шта се указује у стручној литератури, при чему имамо на уму чињеницу да је у раду са страним студентима уџбеник и нека врста медијатора културе и њених вредности (Вујовић 2004; Кончаревић 2005, 2018; Перишић Арсић 2018).

(6) - Хало. Овде Драгана Јовановић.

- Изволите. Овде Нада Костић.

- Да ли је Марија у кући?

- Да. У кући је. (МАРИЈА, ТЕЛЕФОН!)

- Хало, овде Марија! Драгана, ти си?

- Да, ја сам.

- Где си?

- На факултету. Зашто ти ниси на факултету?

- Време је лоше. Киша пада, дува ветар... А предавања данас нису интересантна.

- Марија, у биоскопу је добар филм.

- Какав филм?

- Музички филм.

- То је интересантно.

- Али, пада киша.

- То није страшно. Ту је кишобран. И кишни мантил је ту. (Ћорић 2002: 82)

(7) Марко: Хало?

Павле: Поздрав, Марко. Павле је. Шта радиш? Хоћемо ли ићи на концерт?

Марко: Уопште не знам шта да радим. Иде ми се на концерт, али у понедељак имам испит. Нисам још ни прочитао целу књигу, а камоли нешто научио! Ако одем на концерт, може да се деси да паднем на испиту.

Павле: Па, добро. Марко, није смак света ако не положиш тај испит. Полагаћеш поново у септембру. Ово је јединствена прилика да чујеш тако добру групу уживо.

Марко: У праву си. Идем на концерт, па шта буде. Какав је договор? Где ћемо се наћи?

Павле: Договорили смо се да се нађемо у пет на Тргу, испред Милетићевог споменика. Кад се скупимо, сви заједно идемо на аутобуску станицу. Аутобус за Београд имамо у седам.

Марко: Добро, видећемо се на тргу. Ћао!

Павле: Видећемо се, Марко! (Алановић и др. 2007: 43)

Телефонски разговори врло често се користе у уџбеницима страних језика. У примеру (6) и (7) дијалог садржи основне елементе и формуле (Хало, Овде је, Изволите). У првом иницијални турнуси реализују се између непознатих саговорница и то се препознаје по формалном тону конверзације. Он постаје присан између Марије и Драгане које се одмах препознају као коле- 
гинице са факултета и пријатељице. Следови („Ти си? Где си?”) уводе дијалог са тзв. предследом: „Где си? Зашто ти ниси на факултету?” Ова питања могу да се тумаче као увод у предлог који је после формулисања и оправдања за останак код куће (лоше време, киша, ветар, досадна предавања) у следећем турнусу изричит и састоји се у позиву да се иде у биоскоп. Прихватање следи као изричита акција, тако да читав дијалог карактерише оно што се у литератури назива „,акцијском структуром” (Стевић).

Ипак, и поред тога што је формално овај дијалог добро структуриран, не делује природно: локативна конструкција са предлогом „у” („Да ли је Марија у кући? Да, у кући је”) у свакодневном говору била би сигурно замењена синтагмом „код куће.” Сем тога, не делују аутентично ни конструкције типа: „То је интересантно.” „То није страшно. Ту је кишобран. И кишни мантил је ту.” Можемо да констатујемо да је у овом случају аутор употребио дијалог за утврђивање граматичких деоница претходно обрађених у лекцији и при томе се није удаљио од конструкција које су типичне за механичко увежбавање, али не одговарају реалној говорној ситуацији. Дијалог стога делује исфорсирано, а циљ је шаблонско усвајање језичког знања.

Насупрот томе, у примеру (7) уочава се отварање које је типично за дијалог. Близински пар је уместан и уобичајен, одаје присност и пријатељски однос који постоји између Павла и Марка. Павле препознаје Марков глас и то може да се сматра преференцијским поступком, док његово самопредстављање („Павле је”) није неопходно јер се узајамно препознавање саговорника сматра тзв. претпостављеним, надређеним поступком. У наредним турнусима позив - предлог да се иде на концерт први је предмет разговора али и мотив позива који се уводи од самог почетка. Како се наводи у литератури, овакав поступак није сасвим уобичајен, али се не сматра изузетком јер се ради о младим особама и о присним саговорницима (Стевић 2007: 94-95). Тзв. преференцијска делатност (позив на концерт) овде изискује одговор, али Марко уместо економичног и лаконског (Да/не) нуди ублажени, „умекшани” израз („Уопште не знам шта да радим”) који исказује неодлучност. Образложење које следи је нека врста негоцијације или преговора, при чему су граматичке јединице (презент/футур, перфективни/имперфективни глаголи, конструкција са дативом) успешно уклопљене у дијалог који сасвим одговара природном језичком изразу.

Томе доприносе и конструкције које се користе претежно у младалачком жаргону: „Није смак света”, „Ово је јединствена прилика”, „па шта буде” и др. Говорни језик често карактерише и понављање које је овде врло ефикасно уклопљено у вештачки, дидактички дијалог. Марко каже: „Добро, видећемо се на тргу. Ћао!”, док Павле у свом исказу у знак слагања користи, понавља исти глагол: „Видећемо се.” Затварање дијалога карактерише дакле понављање перфективног повратног глагола у футуру који не делује наметнуто него сасвим одговара природном дијалогу. 
(8) Дан и Тамара треба да се нађу у центру Београда, тачно у подне. Дан не може да нађе место за паркирање и зато касни.

Т: Хало, Дан! Где си?

Д: Тренутно сам у ауту, у Балканској улици. Нема нигде места за паркирање.

Т: Па, кад се онда видимо?

Д: За петнаест минута у кафићу „Молоко” на Тргу републике, може?

Т: Знам где је то. Стижем.

Д: Ћао! (Милићевић Добромиров и др. 2006: 163).

Дијалог број (8) пример је концентрисаног дијалога, састоји се од три турнуса који садрже све делове телефонске конверзације која се одвија путем мобилног телефона. У овом случају у дијалогу се алтернативно смењују питања и одговори, а они су врло учестали у природном језику и по правилу се остварују као употпуњени близински парови, што значи да после првог дела обавезно следи други. Прво Тамарино питање „Хало, Дан! Где си?” тумачимо као израз нестрпљења јер Дан касни на састанак и исказ то јасно рефлектује. Сличан тон је и у другом питању, где речца „па” и временски прилог „онда” још интензивније изражавају Тамарино нестрпљење. Сведеност Дановог одговора на исказ без субјекта и глагола „За петнаест минута...”, који се завршава глаголом „може” у 3. лицу једнине, добар је пример успешног уклапања граматичких посебности говорног језика у дидактичке сврхе. Затварање конверзације у свакидашњици на овај начин није неуобичајено, већ напротив, дијалог је у складу са контекстом те може да се сматра обрасцем изворног разговорног језика.

\section{4. Закључак}

Одломци и дијалози из уџбеника за српски као страни језик, анализирани у реферату, јављају се уклопљени у главни текст или још чешће у сегментима који су намењени увежбавању. За разлику од аутентичног разговорног језика који је у великој мери неграматичан, дијалог у уџбеницима као дидактички материјал увек има „граматичку” функцију и због тога је често артифицијелан. И поред тога, од изузетне је важности ако се узме у обзир чињеница да је то у иностраној средини преференцијални канал преко ког студент открива разговорни језик и навикава се на реални говор у свакодневној комуникацији на разним нивоима. Због ове специфичне функције састављање дијалога у уџбеницима сваког, а посебно имамо на уму српски као страни језик, не треба да буде препуштено случајном одабиру садржаја. Као циљно симулирање реалног говора дијалог треба да се заснива на теоријским знањима како би као артифицијелни образац био веродостојан и аутентичан, а уз то обогаћен одређеним елементима цивилизације и културолошким садржајима који су 
део наставе језика и на тај начин представљају земљу и народ чији се језик учи у иностраној средини.

\section{ИЗВОРИ}

Алановић 2007: M. Alanović, I. Bjelaković, N. Bugarski, J. Dražić et al., Научимо српски 2/ Let's learn Serbian 2, Novi Sad: Filozofski fakultet, Dnevnik.

Бјелаковић 2004: I. Bjelaković, J. Vojnović, Научимо српски 1/ Let's learn Serbian 1, Novi Sad: Filozofski fakultet, Dnevnik.

Милићевић Добромиров и др. 2006: N. Milićević Dobromirov, Lj. Ćuk, N. Radulović, Учимо српски 2/Uс̌imo srpski 2. Srpski za strance srednji nivo, Beograd: Azbukum.

Милићевић Добромиров/Новковић 2009: N. Milićević Dobromirov, B. Novković, Учимо српски 1/Učimo srpski 1, Novi Sad: Centar Azbukum.

Ћорић 2002: B. Ćorić, Srpski za strance. Serbian for Foreigners, sedmo izdanje, Beograd: Čigoja štampa.

\section{ЛИТЕРАТУРА}

Бацанела 1994: C. Bazzanella, Le facce del parlare. Un approccio pragmatico all'italiano parlato, Scandicci (Firenze): La Nuova Italia Editrice.

Бацанела 2002: C. Bazzanella (ur.), Sul dialogo. Contesti e forme di interazione verbale, Milano: Guerini Studio.

Бибер 1988: D. Biber, Variation across Speach and Writing, Cambridge: CUP.

Вилић 2007: I. Vilić, Nastavnik u komunikativnom pristupu u nastavi srpskog jezika, Savremene tendencije u nastavi jezika i književnosti, Zbornik radova, (prir.) J. Vučo, Beograd: Filološki fakultet, 224-230.

Вујовић 2004: A. Vujović, Kratak istorijski pregled izučavanja strane civilizacije u okviru nastave stranog jezika, Pedagogija, 59 (1): 68-79.

Де Maypo 2004: Т. De Mauro, Il dizionario di italiano compatto, Torino: Paravia.

Клајн/Шипка 2010: I. Klajn, M. Šipka, Veliki rečnik stranih reči i izraza, peto dopunjeno i ispravljeno izdanje, Novi Sad: Prometej.

Кончаревић 2005: К. Кончаревић, Презентација српске културе у уџбеницима српског језика као страног - теоријски оквир и конструкцијска решења, Научни састанак слависта у Вукове дане, 34/1, 217-228.

Кончаревић 2018: К. Кончаревић, Језик и култура: славистичка перспектива, Београд: Јасен.

Mep 1981: W. N. Mair, „Français parlé” et „Français écrit”: remarques sur les rapports entre „modes de manifestation linguistique” et „modes de production signifiante", Lingua e stile, XVI, 1, pp. 151-162.

Нушић 1962: B. Nušić, Autobiografija, Beograd: Kultura.

Перишић Арсић 2018: O. Perišić Arsić, Različiti aspekti kulture u udžbenicima srpskog jezika kao stranog za srednji nivo Sretan put i Učimo srpski 2, in: Su- 
sret kultura, (prir.) I. Živančević Sekeruš, Ž. Milanović, Novi Sad: Filozofski fakultet, 95-105.

Пјаца 1995: R. Piazza (ур.), Dietro il parlato. Conversazione e interazione verbale nella classe di lingua, Scandicci (Firenze): La Nuova Italia Editrice.

Пољаковић 1993: I. Poljaković, Dijalog i njegova funkcija u nastavi stranog jezika, Zbornik radova Građevinskog fakulteta, 9, Subotica: Univerzitet u N. Sadu, 301-308.

Поповић 2007: T. Popović, Rečnik književnih termina, Beograd: Logos Art.

Пожгај Хаџи/Смолић 1996: V. Požgaj Hadži, M. Smolić, Jezični sustav i komunikacija u procesu usvajanja hrvatskog kao stranog jezika, in: Jezik $i$ komunikacija, ur. M. Andrijašević - L. Zergollern, Zagreb: HDPL.

Пожгај Хаџи 1999: V. Požgaj Hadži, M. Benjak, Pristup polifunkcionalnosti jezičnog diskursa (dijaloga) u udžbenicima hrvatskog jezika kao stranog/drugog, in: Teorija i mogućnosti primjene pragmalingvistike, Zbornik, ur. L. Badurina, N. Ivanetić, B. Pritchard, D. Stolac, Zagreb - Rijeka.

Стати 1982: S. Stati, Il dialogo. Considerazioni di linguistica pragmatica, Napoli: Liguori editore.

Стевић 1987: S. Stević, Jedan pokušaj analize dijaloga, S. Grubačić (ur.), Odnos između jezika i književnosti u istraživanju i nastavi, zbornik radova sa istoimenog savetovanja održanog u Beogradu 28-29. marta, Beograd: Društvo za primenjenu lingvistiku Srbije, 63-66.

Стевић 2007: S. Stević, Italijanski razgovorni jezik kao izvor didaktičkog dijaloga, Savremene tendencije u nastavi jezika i književnosti, Zbornik radova, (prir.) J. Vučo, Beograd: Filološki fakultet, 92-103.

Цингарели 1970: N. Zingarelli, Vocabolario della lingua italiana. Decima edizione, Bologna: Zanichelli.

Ljiljana M. Banjanin

\author{
THE LANGUAGE SPOKEN IN THE ACQUISITION OF SERBIAN \\ AS A FOREIGN LANGUAGE
}

\begin{abstract}
Summary
The development of communicative competence in the study of the foreign language existed also in the past, although only from the eighties of the 20th century, in teaching begins the perception of its central position in the teaching of the foreign language in general and therefore also of Serbian, from the earliest stages of study. In this article, the starting point is the theoretical framework and the definition of communicative competence and in particular of the natural forms of communication (dialogue). The aim is to give an answer to the question whether the dialogues in the teaching material for foreign students available to teachers correspond to the real/natural situation and which are the culturological messages they offer.
\end{abstract}

Keywords: Serbian as a foreign language, communication, spoken language, dialogue. 